\title{
Creating H5P content for active learning
}

Rachelle Singleton

The University of Auckland

r.singleton@auckland.ac.nz

Amanda Charlton

Auckland District Health Board

ACharlton@adhb.govt.nz

Submission Type: Workshop (100mins)

Keywords: H5P, active learning, student engagement, blended course delivery

\section{Abstract:}

Active learning is a popular and proven method used in contemporary educational design and practice. H5P (https://h5p.org/) facilitates easy creation of richer HTML5. Integration of H5P content within course material provides opportunities for students as learners to think critically about what they are being taught and supports the flexibility students are requesting by extending the learning environment. A variety of activities can be developed; case study scenarios, interactive technical demonstrations, 3D images with identification of regions of interest (hotspots; roll-over information; animation), as well as quiz questions in a wide variety of differing formats; fill in the blanks, image and text-based drag and drop, mark the word, interactive video and branching scenario tasks. H5P content can be easily shared across multiple learning management systems (Canvas, Moodle, and Blackboard). We have used H5P activities to formatively assess student comprehension of content taught in undergraduate anatomy, physiology and pathology courses, ensuring specific learning outcomes are achieved. Learners receive comprehensive, automatic feedback and their engagement with H5P activities can be tracked by teachers. H5P is broadly applicable /can be used within a wide variety of teaching contexts/subject areas.

\section{Outcomes}

At the end of this 100 min workshop you will have created and shared your first H5P activity, and will be able to do it again.

\section{Major features to be investigated}

Structured into 4 steps, discussion and demonstration of pros and cons of

1. H5P.org versus H5P.com (unlicensed versus licensed service)

2. How to install a H5P content type and create and edit $\mathrm{H} 5 \mathrm{P}$ content

3. How to use many of the existing H5P content types

4. How to share your created content

\section{Session organisation}

\begin{tabular}{|l|l|l|}
\hline 5 tables. 4-6 participants per table. & Content \\
\hline Time (mins) & Activity & $\begin{array}{l}\text { Table group introductions, share experience with creating online } \\
\text { content and intended uses, table group discussion and whole } \\
\text { group Post-it notes. }\end{array}$ \\
\hline 10 & $\begin{array}{l}|c| \\
\text { Icebreaker }\end{array}$ & What is H5P and why would I use it? \\
\hline
\end{tabular}




\begin{tabular}{|l|l|l|}
\hline 5 & Participants create a free account in H5P.org. \\
\hline 10 & $\begin{array}{l}\text { Individuals } \\
\text { Active learning guide with tips and techniques. Access to } \\
\text { workshop padlet. }\end{array}$ \\
\hline 30 & $\begin{array}{l}\text { Individuals } \\
\text { Individuals and as a group }\end{array}$ & $\begin{array}{l}\text { Share your H5P content (padlet) and test it out. Self-critique and } \\
\text { partner feedback using a structured framework. } \\
\text { now have 30 minutes to create your own H5P content. }\end{array}$ \\
\hline 5 & \begin{tabular}{l} 
Break \\
\hline 10
\end{tabular} & $\begin{array}{l}\text { Placing an H5P learning interactive into your learning } \\
\text { management system (LMS) }\end{array}$ \\
\hline 5 & $\begin{array}{l}\text { Evaluation Survey } \\
\text { Demonstration }\end{array}$ & $\begin{array}{l}\text { QR code to online survey on phone } \\
\text { Resource links. }\end{array}$ \\
\hline 5 & Discussion and Post-it notes. \\
\hline 5 & & \\
\hline
\end{tabular}

\section{Resources for distribution}

We will be using the free version of H5P (H5P.org), accessed online. A printed step by step active learning guide with URL links to helpful resources will be provided.

\section{Expectations and requirements of participants}

You need to bring your own laptop to participate, or pair with someone who has. Although engaging with H5P content is possible on a tablet or phone, it is recommended you create H5P content on a laptop.

\section{References}

Bonwell, C.C., and Eison, J.A. (1991). Active Learning: Creating excitement in the classroom. ASHE-ERIC Higher Education Report No. 1. Retrieved from https://files.eric.ed.gov/fulltext/ED336049.pdf

Freeman, S., Eddy, S. L., McDonough, M., Smith, M. K., Okoroafor, N., Jordt, H., \&amp; Wenderoth, M. P. (2014). Active learning increases student performance in science, engineering, and mathematics. Proceedings of the National Academy of Sciences, 111(23), 8410-8415. doi:10.1073/pnas.1319030111

Hake, R. (1998). Interactive-engagement vs traditional methods: A six-thousand student survey of mechanics test data for introductory physics courses. Retrieved from http://www.montana.edu/msse/Data analysis/Hake 1998 Normalized gain.pdf

Rekhari, S. \& Sinnayah, P. (2018). H5P and Innovation in Anatomy and Physiology Teaching. Refereed Paper Presented at the 2018 HERDSA International Conference at the University of South Australia, July 2-5, 2018. HERDSA: (Re) Valuing Education.

Yale Centre for Teaching and Learning. Active Learning (2018). Retrieved from https://ctl.yale.edu/ActiveLearning 